\title{
The Model and Structure of the Slovak Catholic Police Chaplaincy
}

\section{ÍRÓ Sándor ${ }^{1}$}

This study introduces the military ordinariate that was created to provide pastoral care for the members of the army and the forces of law and order of the Slovak Republic; it analyses and examines the organisational structure and tasks of it. Policemen during their police work have to face many issues (such as fatal accidents, homicide, burnout, the thought of leaving the field, corruption, personal problems, the question of weapon-holding, personal and social prejudice, suicide, racism) that they cannot understand, process or handle effectively. In such cases they need help. Police Chaplaincy services work in many countries inside the institutional framework effectively helping the job of the police. The institutional background and structure of the Slovak Police Chaplaincy must be examined, considering that Hungary's and Slovakia's historical and cultural traditions are closely related, so during the build-up of the Hungarian Police Chaplaincy, this can provide useful guidance for the ecclesiastical and state leaders.

Keywords: Slovak Catholic Police Chaplaincy, the function of the Police Chaplaincy in the national police system, institutional background and structure, state-church cooperation, international comparison of police chaplaincies

\section{Introduction}

The necessity of the army's and police's pastoral care was already researched by many researchers in the past few years. ${ }^{2}$ These showed that both the military staff and the policemen work in such a unique environment that can demonstrably have a significant effect on the individual's psychological and moral aspects. These researchers analysed and drawn up new scientific evidence about the scientific relations of pastoral care, primarily focusing on the mentioned military and law enforcement related professions. ${ }^{3}$ Both theoretical and practical researches have shown that the policemen's psychological, ethical and moral support (in order to effectively handle the modern challenges of law enforcement) constantly gets more and more necessary to handle in an institutional form, as we can see it in many foreign countries. ${ }^{4}$ This need is

\footnotetext{
ÍRÓ Sándor, official pastor, parish priest of Vérteskethely, National University of Public Service, Doctoral School of Military Science, doctoral candidate.

https://orcid.org/0000-0002-9574-4293, irosandor@gmail.com

2 Ujházi (2014)

Szabó (2016a)

4 Szabó (2014)
} 
understandable considering the new challenges of the Hungarian law enforcement (migration-crisis, terror- and cyber threat); in addition, the renewal of classic crime forms makes the police staff's job even more difficult.

Besides the growing and dynamically changing law enforcement challenges, we have to mention the police's new official service act and the police officers' educational reform. We can witness the changes that improve the police's job and make it even more effective. Due to these effective changes, the people's feeling of security has grown and the number of high-profile offenses and fatal accidents have decreased. These positive results cannot be achieved without the police staff's positive personal and professional attitude. It is important that the police supports the police staff's psychological, moral and ethical development on a corporate level. ${ }^{5}$

In the past few years, the need for security on both individual and social level showed a growing tendency. The new types of security challenges such as international terrorism, the proliferation of weapons of mass destruction, the unstable states, the global environmental issues and the international migration all caused the extension of the word security.

On both the individual and community sides, there are concerns about the sudden and unexpected changes of Europe's whole security system.

The growing concerns and risks about security require even more serious efforts from the state in order to maintain the public order and public security. The basic task of the law enforcement bodies - mainly the police - is to prevent crime and to protect the public security and public order. The law enforcement bodies have to face such challenges (mass irregular migration, terrorist acts in the developed countries using asymmetrical methods or special weapons, the question of the necessity of the militarisation of law enforcement bodies, self-defence ability empowerment in the aspect of the private security sector, the protection of the highlighted infrastructures based on citizen needs, the question of protection of the entertainment facilities) that require the development of the presently used law enforcement abilities in order to be able to handle these effectively and to get the desired results. Reflecting on the new type of challenges of law enforcement, the law enforcement ability development will only be more effective if the law enforcement's decades-old conventional organisational structure's theoretical and practical borders can be overcome. The goal is creating an efficient and secure complex law enforcement structure which can show applicable results in order to handle the new type of challenges of law enforcement effectively. This security complex has to involve the police chaplaincy service which can provide efficient support and guidance to save the Christian religious views and values of the policemen during the ethical and moral issues they might face while handling the new type of challenges of law enforcement. ${ }^{6}$

Szabó-Író (2018)

Szabó (2012) 


\section{The Structure of the Military Ordinariate of Slovakia}

In 1994, a bilateral agreement was made between the Republic of Hungary and the Holy See on the army's and the then existing Border Guard Service's pastoral care. The question of how to extend the rightful areas of activity of the military ordinariate to the police came up many times in connection with the Border Guard Service regarding that the police staff also work and live in a similar, special environment. But in Hungary, it has not been implemented so far. However, in the neighbour country, it was developed in a whole different way. The diplomatic questions between the Republic of Slovakia and the Holy See were regularised in a concordat in 2000. Based on this, a bilateral agreement was made on the army's pastoral care. Although in Slovakia not only the members of the army but the policemen and other armed forces are also provided with pastoral care. The centre of the ordinariate is based in the capital, Bratislava. The main church of the ordinariate is the Saint James parish church. The leader of the ordinariate is NOT the Ordinariate Bishop, although he is member of the pontifical order. According to the legislation, in case the bishop is being prevented from fulfilling his responsibilities, the general vicar should handle his duties. ${ }^{7}$

In the ordinariate, the priests and deacons serve as pastors. ${ }^{8}$ The appointed priests get into an official legal relationship with the law enforcement body they are serving as pastors. The priests have to serve wearing uniforms with their appointed law enforcement body's mark and their own officer position and military rank on it. The pastors' allowance is provided by the Slovak Ministry of the Interior and the head of their service place is their employer. ${ }^{9}$

\section{The Task System and Structure of the Military Ordinariate of Slovakia}

The Military Ordinariate of Slovakia started to operate on the 1st of March 2003. ${ }^{10}$ Contrary to its name, the ordinariate did not only provide pastoral care for the Slovak army members. It also provides pastoral care to the Slovak police staff, the Slovakian Customs and Finance Guard, the Railway Police, the members of the official security service of the Court of Justice and to the employees of the law enforcement bodies. The

\footnotetext{
Article 11 (1) If the Ordinariate is attacked, and unless the Holy See decides otherwise, the Ordinariate's management will be taken over by his substitute, who, according to the canonical rules, has the same duties and authorities of the local Ordinary, except for items extracted by the law. Available: www.ordinariat.sk/statut-ordinariatu-ozbrojenych-sila-ozbrojenych-zborov-sr/ (Downloaded: 03.02.2019.)

8 Hlava V. Klérus Ordinariátu. Article 22 (1) The presbytery of the Ordinariate consists of secular and religious priests and deacons serving in the Ordinary. Available: www.ordinariat.sk/statut-ordinariatu-ozbrojenych-sil-a-ozbrojenychzborov-sr/ (Downloaded: 03.02.2019.)

9 Štatút Ordinariátu ozbrojených síl a ozbrojených zborov SR. Available: www.ordinariat.sk/statut-ordinariatu-ozbrojenych-sil-a-ozbrojenych-zborov-sr/ (Downloaded: 07.01.2019.)

10 Ordinariát ozbrojenych síl a ozbrojenych zborov Slovenskej Republiky. Available: www.ordinariat.sk/ (Downloaded: 03.02.2019.) On inquiring the Military Ordinariate of Slovakia, it is stated that all the documents and information are available, which are related to a relevant event related to the life of the ordinariate. Information is also given about the structure and the history of the organisation.
} 
ordinariate provides pastoral care for prisoners, as well as for the employees and civil servants of official bodies. ${ }^{11}$

\section{Objectives of the Slovak Policemen's Pastoral Service}

1. The centre of the urban district directory of the police office is the place of the occupation.

2. It prepares and develops the scope of duties of the pastorate in the spirit of the vicariate, within the framework of the Ministry of the Interior.

3. It helps to deal with the psychological problems of policemen and their families according to their needs. (In some cases also provides this care to detained people or to people in protection programmes.)

4. It ensures and provides pastoral care in the Érsekújvár police offices and the departments under it.

5. It prepares the sacraments and performs them.

6. It helps to deepen the policemen's and other police staff's moral and patriotic feelings.

7. It provides psychological aid services to each individual and to the community altogether with questions of psychological nature and offers counselling and consultations.

8. Cooperates with the Ordinariate in order to reach a homogeneous pastoral attitude.

9. Participates at the work-related and psychological conventions of the Ordinariate.

10. Participates on the priestly recollections which are held at the appointed duty areas, collaborates in the coordination of the pastoral duties and with the priest of the diocese.

11. It provides registry services (baptism certificates, chronicles, archives).

12. Collaborates with the representatives of each state-recognised religion.

13. Familiarises with the work of the police officers in the urban districts and the offices under them.

14. It fulfils the tasks derived from the decisions of the ordinariate, following the instructions of the vicariate.

15. It follows the vicariate's instructions.

The effectiveness of the created structure of the Slovak Catholic Ordinariate is undeniable. The police pastors can organise and provide pastoral care at their discretion. ${ }^{12}$

11 According to the related legislation, in addition to the members of the official bodies inside the active staff, the Ordinariate supplies the pastoral care of those who are retired, suffer long-term illnesses, students, and the active officers' family members. Štatút Ordinariátu ozbrojených síl a ozbrojených zborov SR. Article 5, paragraph 2, point e).

12 The official pastor of the City Police Department of Párkány, during our personal meeting expressed that besides the completion of pastoral care, the official pastor can also fulfil the classical policeman's roles: e.g. traffic control, speed cameras, patrol service. The official pastor stated that during duty - in most cases - he is present as a third party, in uniform, without a gun and compelling tools. The pastoral trait is marked on the police uniform as a distinctive sign. 


\section{Conclusions and Proposals}

The Catholic church has not created a common pastoral institution for the policemen's pastoral care.

Some tendencies can be distinguished though, when talking about the pastoral care of policemen.

The most typical can be mainly observed in the South American countries, i.e. the Military Ordinariate provides the police's pastoral care.

In these cases, the legislature proceeds from the similarities of the two or more armed forces or most likely from the fact that there are armed forces.

In these countries, there are differences between the control of the military ordinariate's power and the local ecclesiastical body's pastoral care. The details many times cannot be figured out even from the ordinariate's internal rules. The advantage of this solution is that the police's pastoral care has to be provided within the framework of the existing international agreement. This also has a certain financial benefit. On the other hand, the disadvantage of this solution is that it does not consider the differences between the psychological challenges of the police staff and the army. That is why it is justified to create a separate pastoral institution for this purpose. The Slovak example perfectly shows that both the Slovak Catholic Church and the government recognised the importance of the police staff's pastoral care. This kind of pastoral care that is provided through a military ordinariate can be observed in other European countries, too. It is observable that the newly created military ordinariates - such as the Slovak or the one in Croatia - got very extended jurisdictions, too. The legislature is still considering it a preferred solution, if the police's pastoral care has to go within an institutional frame, then it should be kept within a military ordinariate. In cases like this, it should be considered that the extending jurisdiction and significant growth of the number of staff members has an extending financial consequence to the military ordinariate. This has to be contracted between the given state and the Catholic Church. In many cases, the local Catholic Church cannot take the personal responsibility that is needed for the development of such a system, for example, in Hungary, the military ordinariate has only fifteen positions that are provided by the state to be filled. In other countries such as the United States of America, South Korea or the Republic of South Africa, the Bishops try to organise the pastoral care for the police locally. These are local initiatives without a stable legal background and working structure. The advantage of this system is that it can be more personalised for the local police's needs. In many cases, the local pastors provide this service who undertake this task in addition to their everyday job. In this structure, there are many secular helpers who without the education or the needed suitability can be doubtfully called helpers. There are mixed models, too. In Italy, the carabinieri are under the authority of the military ordinariate when the police's

When talking about these facts, the question arises: At a possible check during patrol services, how and to what extent can official pastors implement their authority; because they attend the service without a gun and compelling tools. 
pastoral care is provided by a body that is under the authority of the Bishop. This, latest one is a pastoral institution on a local level but has a serious legal framework and a strong personnel basis. The creation of this in Hungary has not been fulfilled. Even though there were initiatives that the Hungarian Military Ordinariate should only provide pastoral care for the Civil Disaster Protection, this failed because of the lack of a serious intention from both governmental and ecclesiastical sides. Slovakia has a very similar historical and political background to Hungary which is shown even in the momentary structure of the police. In post-communist Slovakia, there are nearly the same safety factors (organised crime, drug trafficking, corruption) as are in Hungary and it has an effect within the police. So this is the country that we can use as the closest example in the development of Hungary's pastoral care system. ${ }^{13}$ The different international models prove that the legislature, the local ecclesiastical administration, the state and the police bodies all consider it important to create a working pastoral care system. The Police Chaplaincy can bring solutions for such safety issues like the recognition and handling of attacks on the Catholic priests in the Member States of the European Union. ${ }^{14}$ The Catholic priests serving in the Slovak Police Chaplaincy have to participate in a training about the law enforcement body's training and educational system so that they can identify - and in some cases localise - more easily the safety problems both on the territory of the Catholic institutions and during the work on the communal areas. In this present study, the structure model of the Slovak Police Chaplaincy has been introduced together with the successive and closely connected areas focusing on and examining the police's side. The legislation, the institution's character, the relevance, the directory, the office body system, the service clergy, the priests' education, the pastoral care's subjects and the international safety environment are related areas which can together introduce the Slovak Police Chaplaincy.

\section{REFERENCES}

Hlava V. Klérus Ordinariátu. Presbytérium ordinariátu tvoria svetskí a rehol'ní kňazi a diakoni, ktorí v ordinariáte vykonávajú službu. Available: www.ordinariat.sk/statut-ordinariatu-ozbrojenych-sila-ozbrojenych-zborov-sr/ (Downloaded: 02.03.2019.)

Ordinariát ozbrojenych síl a ozbrojenych zborov Slovenskej Republiky. Available: www.ordinariat.sk/ (Downloaded: 12.16.2016.)

Police Chaplaincy (s. a.). Available: http://mysite.mweb.co.za/residents/bloemomi/Police-Chaplain. html (Downloaded: 01.08.2019.)

Štatút Ordinariátu ozbrojených síl a ozbrojených zborov SR. Available: www.ordinariat.sk/statut-ordinariatu-ozbrojenych-sil-a-ozbrojenych-zborov-sr/ (Downloaded: 01.07.2019.)

Szabó Csaba (2012): Az Európai Unió és Magyarország biztonsági stratégiájának vizsgálata a szélsőséges vallási csoportok vonatkozásában. Szakmai Szemle, No. 2. 80-92.

13 Szabó (2016b)

14 Szabó (2018) 
Szabó Csaba (2014): A rendészeti dolgozók katolikus lelkipásztori gondozása Európában. In Kiss Petra ed.: A hadtudomány és a 21. század: Konferenciakötet. Budapest, Doktoranduszok Országos Szövetsége. 243-259.

Szabó, Csaba (2016a): Examination of the Importance of Patron Saints and Prayer Books in Relation to Pastoral Care in the Police. Magyar Rendészet, Vol. 16, No. 2. 187-193.

Szabó Csaba (2016b): A katolikus rendőrségi lelkipásztori modell válaszai a rendőrök erkölcsi és pszichikai problémáira. In Szabó Csaba ed.: Studia Doctorandorum Alumnae I.: Válogatás a DOSz Alumni Osztály tagjainak doktori munkáiból. Budapest, Doktoranduszok Országos Szövetsége. 415-417.

Szabó, Csaba (2018): Examination of the Need for a Directive to Strengthen the Control over Possession of Firearms Envisaged by the European Commission in the Context of New Types of Security Challenges Affecting the European Union. Hadmérnök, Vol. 13, No. 3. 486-494.

Szabó Csaba - Író Sándor (2018): A katolikus rendôrségi lelkipásztori szolgálat modellje. Budapest, Doktoranduszok Országos Szövetsége. 215-127.

Ujházi Lóránd (2014): A katolikus katonai ordinariátus struktúrája és szabályozása. Budapest, Szent István Társulat. 35-37. 